\title{
Analytical, System-Structural, Formal-Logical Approaches Towards the Institution of Restrictions
}

\author{
${ }^{1}$ Galina S. Belyaeva, ${ }^{2}$ Ekaterina V. Butova, ${ }^{3}$ Aleftina H. Gacolaeva, ${ }^{4}$ Juliya A. Krylova, ${ }^{5}$ Andrey S. Mamin \\ 1,2, 4, 5 Belgorod State University, 85 Pobedy Str., Belgorod, Belgorod Region, 308015, Russia \\ ${ }^{3}$ North Ossetian State University, 44-46, Vatutina Str., North-Ossetia Alania, Vladikavkaz, 362025, Russia \\ Email: belyaeva_g@bsu.edu.ru
}

Received: $16^{\text {th }}$ May 2018, Accepted: 04 ${ }^{\text {th }}$ June 2018, Published: $30^{\text {th }}$ June 2018

\begin{abstract}
This paper raises some issues regarding the institution of restrictions as a public-law category. The state of scientific study of the problem, its origins, evolution and modern embodiment is analyzed. The criteria and conditions for the restriction of human and citizen's rights and freedoms in national legislation are established. Based on the results of the study, a conclusion was made on the role of law as the main form of fixing restrictions in the public sphere.
\end{abstract}

Keywords: Restriction, Institution of Restrictions, Restriction of State Power, Restriction of Human Rights, Law

\section{Introduction}

In legal doctrine, the problem of the concept, essence, and content of the institution of restrictions, due to the complexity and multidimensionality of the latter, is debatable. The subject of numerous studies is the socio-legal and political and legal restrictions in the exercise of state power (governance), the essence and content of restrictions in the general legal terms, restrictions on the rights and freedoms of the individual (person, citizen), concepts, notion and system of restricting state power. Restrictions are subjected to research from various positions and points of view: the needs of a particular kind of social relations and the appropriate legal means of influencing them; as methods and ways of legal regulation; and as the principles and functions of law. This is no accident, since, as E.A. Sedov rightly notes, "the search for the optimal balance between the provision of the necessary freedom to every member of society and the reasonable restrictions of this freedom for maintaining public order have been and are one of the most complex, sensitive and urgent social problems for all human communities" [1].

Indeed, the formation of civil society and the rule of law is closely intertwined with the restrictions. On the one hand, a rather unilateral fascination of some legal scientists in recent decades with the ideas of inviolability of rights and freedoms in the legal status of the individual has inevitably led to the fact that the rights of some members of society have come into conflict with the rights of others, with common and public interest. This gave rise to the problem of finding a balance in the system of rights, freedoms, duties and restrictions of the legal status of the individual in order to maintain stability in the country, ensure the conditions for the existence of each individual and the progressive development of society and the state. On the other hand, the fundamental signs of the rule of law are also related to restrictions, such as the partition of powers, the restriction of power to law and human rights, otherwise state power risks becoming a spontaneous uncontrolled phenomenon, devoid of its main purpose - serving the interests of the individual and society.

Therefore, it is fair to recognize the opinion of the French law scholar J. Selle about the nature of power: "The foundations of any power are overarching and totalitarian; all power tends to be absolute inside and dominant outside the system" [2].

It is necessary to pay attention to the dual (and even contradictory) nature of the restriction of state power: on the one hand, it is an absolute blessing, since it ensures the implementation and protection of human rights and freedoms; on the other, the state must be strong to ensure protection of civil rights by the potential possibility of using means of state coercion. Thus, according to the German law scholar R. Iering, "the weakness of power is the mortal sin of the state, which is less forgiven to leaders than cruelty and arbitrariness" [3].

Thus, restrictions are necessary, both in terms of deterring abuse of rights and misconduct of individual citizens for the sake of general (public) interest, and the arbitrariness of the state as a whole and state bodies (officials) in particular.

\footnotetext{
Methodology

The methodological basis of the research is formed on the basis of the application of various general scientific methods and ways of scientific knowledge (analysis, synthesis, deduction, induction, systemstructural, formal-logical approaches), as well as specific scientific methods - historical legal, formal legal, comparative legal and interpretative.
} 


\section{Discussion and Results}

We shall start our study with the note that there is currently no single conceptual theory (the official doctrine) of legal restrictions: restrictions of the rights and freedoms of the human and the citizen and state power, as well as the fact that the institution of restrictions has not been investigated, as the legal reality requires.

In particular, serious questions today are caused by the lack of a uniform approach to the general theoretical interpretation of the concept of legal restrictions applied to various subjects of law (individual and collective) in legal science and practice, and, as a consequence, the inability of sectoral legislation to regulate the relations in question concerning the established sphere of legal effect. The legal system (including the domestic one) more than ever needs a comprehensive and systematic general theoretical study of the institution of restrictions, its concept, essence, content, structure and functions.

It is noteworthy that the problem of searching for criteria for restricting public power arose in the ancient centuries in the works by Aristotle, Plato, Panetia, Polybius, Lucretia, Cicero about the three main forms of government (monarchy, aristocracy, democracy), the development of this evolutionary chain and deviations from "right" forms, etc.[ 4].

In the later period, the concepts of the restriction of state power were also developed in the doctrine of the right to war and peace by G. Grotius [5], the theory of the state by T. Hobbes [6], the theory of separation of powers by S. Montesquieu [7], the theory of social contract by J.-J. Rousseau [8], the doctrine of law by I. Kant [9], the philosophy of law by G.W.F. Hegel [10], the doctrines of the limits of state activity by W. Humboldt [11], of the "struggle for the right" by R. Jhering [3], of the social transformation of law and state by L. Duguit [12], of the constitution and sovereignty of the state by C. Schmitt [13], the institutional theory of public law by M. Hauriou [14] and many others [15].

However, no unambiguous approach to the question of their legal nature has been received, since the concept of public legal restrictions had various embodiments in different periods.

Thus, at first, as a public legal restriction, the idea of a "counterweight" was proposed, which recognized other authority as the main criterion for restraining state power: the divine power was recognized in the doctrines by F. Aquinas [16], the constituent power by J. Locke [17], and democratic power - by J.-J. Rousseau [18].

Later, the idea of separation of powers emerged, which at the legislative level was most vividly embodied in the US Constitution as follows: "The legislative, executive and judicial bodies should be divided and different, so that none of them could use the authority that definitely belongs to another: a person cannot simultaneously exercise power greater than the power of one body" [19].

Consequently, the right (and law as its basic form) was recognized as the most important and universal way of setting forth public restrictions.

However, in the opinion of M. Horwitz, the rule of law as restriction of state power protects the citizen, but at the same time he gives it to the power of soulless forms that have replaced the arbitrariness, deprived of the possibility to take into account the human factor (suffering, helplessness, etc.): "The rule of law creates a formal equality, which is an important virtue, but contributes to inequality by creating a consciousness that radically separates right from politics, goals from means, processes from the results" [20].

Therefore, human rights currently come to the fore as a criterion for limiting state power, which in turn can also be limited by the state in certain situations, such as the protection of the foundations of the constitutional order, morality, health, rights and legal interests of others, ensuring the country's defense and state security, etc.

The theory of the restriction of power to human rights received its real legal embodiment in international instruments by pointing out the primacy of human rights and the permissibility of restricting them only according to certain goals. Part 2 of Article 29 (2) of the Universal Declaration of Human Rights stipulates that "in the exercise of his rights and freedoms, everyone shall be subject only to such limitations as are determined by law solely for the purpose of securing due recognition and respect for the rights and freedoms of others and of meeting the just requirements of morality, public order and the general welfare in a democratic society" [21].

This provision was also set forth in the International Covenant on Economic, Social and Cultural Rights, opened for signature on December 16, 1966. Restrictions must be carried out, according to Art. 4 of this Covenant, solely "in order to promote the general welfare, to be determined by law, and they cannot contradict the nature of the rights being restricted" [22].

Restriction of the rights and freedoms of citizens is established in domestic (national) legislative acts in two main ways: either by setting forth additional conditions, prohibitions and duties that restrict the exercise of subjective rights and freedoms, or by increasing the powers of state authorities and their officials, or both simultaneously. The result is the same - a reduction in the options for possible behavior that constitute the content of the subjective rights and freedoms of citizens. 
We should note that the forms of restriction of citizens' rights and freedoms provided for by legislation can be different: a ban on a certain version of the realization of law or freedom, that is, the establishment of the boundaries of conduct (relative prohibition); a ban on the execution of the right (freedom) in general (or absolute prohibition); interference (intrusion) of authorized state bodies into the subjective right (freedom) of a citizen; duty; and responsibility.

In our opinion, in order to prevent an arbitrary restriction of the rights and freedoms of citizens and abuses by public authorities in this area, there are clear criteria for restricting these rights:

- the legal basis for the restriction of human rights should be only the law - the Constitution (the basic law), constitutional or ordinary laws;

- the purpose of restricting human rights is the protection of the foundations of the constitutional order, morality, health, rights and legal interests of others, ensuring the country's defense and state security;

- conditions for the establishment of such restrictions (necessary in the aggregate) - a real or potential possibility of causing harm to the state and public interests; impossibility to protect the said interests by other means; proportionality of imposed restrictions; and if the harm caused is less than that prevented;

- Restrictions should be of a general (nonpersonalized) nature, not retroactive, and should not change the essence of the most restricted constitutional law (freedom);

- Restrictions should correspond to the generally recognized principles and norms of international law;

- Restrictions should neither concern fundamental human rights and freedoms nor be discriminatory;

- The law restricting the rights and freedoms of citizens must be clearly formulated and allow no arbitrary (spread or restrictive) interpretation.

Finally, we should say a few words about the convergence-based approaches to limiting state power. They are developed by the proponents of the discursive theory of law, which was formed within the framework of the communicative theory of the society by J. Habermas, based on the interconnection (interdependence) of human rights and the idea of democracy, the idea of people's sovereignty [22].

According to this concept, legitimacy is not reduced to legal formalization or the ability of the authorities to effectively use the resources of violence; legitimacy is the laws that embody the basic principles of law: social harmony, social compromise, and social justice.

Thus, the idea of restricting state power to human rights best fits into the Western concept of human rights, which treats the human rights as a requirement for the state to commit or refrain from doing certain actions; a means of combating the abuse of state authorities. Human rights are a means of combating abuse of power, since of all the above "internal" criteria for limiting state power, they alone are an indispensable "external" factor of controlling its activities, a peculiar manifestation of the power of the individual, and the will of civil society.

Opponents of this theory argue that the recognition of human rights as primary in relation to the effectiveness of governance can cause powerlessness of state power, which, in turn, threatens security and freedom and can become a determining factor for establishing arbitrariness. Continuing this idea, we can unreasonably oppose state power and freedom. However, the restriction of human freedom by state power is at the same time a necessary condition for its provision and protection. Thus, in reality legal freedom is confronted only by state power, not restricted to law.

\section{Summary}

The results of the study allow us to conclude as follows: the institution of public law restrictions has a long history; its conceptual foundations originated in ancient times, have made a long way in their formation and development and are now consolidated in international legal instruments and constitutional acts of various states.

As the final of the analysis of the problem stated in the paper's title is an indisputable fact that the right (in its natural and legal manifestations) as the official civilized, universal and most effective regulator of social relations, the most important social, cultural and moral value, the measure of freedom, and the responsibility of the individual must be the main form of setting forth restrictions for both state power and the rights and freedoms of the human and citizen.

\section{References}

1. Sedov, E.A. Informacionno-ehntropijnye svojstva social'nyh sistem. Obshchestvennye nauki i sovremennost'. 1993. № 5. (In Russian)

2. Scelle, G., 1948. Manuel de droit international public. Cours de droit international public / 3rd ed. Paris: Domat-Montchrestien.

3. Jhering, R. 1915. The Struggle for Law. Chicago: Callaghan and Company.

4. Marias, J., 2012. History of Philosophy. Courier Corporation.

5. Neff, S., 2012. Hugo Grotius. Cambridge University Press.

6. Hobbes, T., 2010. Leviathan, Parts I and II. Revised Edition. Broadview Press. 
7. Montesquieu, C., Richter, M., 1970. The Politcal Theory of Montesquieu. CUP Archive.

8. Wraight, C., 2008. Rousseau's 'The Social Contract'. A Reader's Guide A\&C Black.

9 Kant, I., 2010. Groundwork of the Metaphysics of Morals: A German-English Edition. Cambridge University Press.

10. Hegel, G., 2008. Outlines of the Philosophy of Right. Oxford University Press.

11. Humboldt, W., 1969. The limits of state action. Cambridge University Press.

12. Duguit, L., 1917. The Law and the State. Harvard Law. Review Nov., 31(1): 1-185.

13. Schmitt, C., 2008. The Concept of the Political. Expanded University of Chicago Press.

14. Hauriou, M., 1929. Precis de Droit Constitutionnel. Paris: Librairie du Recueil Sirey.

15. Belyaeva, Galina S., Makogon Boris V., Bezugly Sergej N., Prokhorova Marina L., Szpoper Dariusz, 2017. Basic Ideas of State Power Limitation in Political and Legal Doctrine. Journal of Politics and Law, vol. 10, No. 4, pp. 197-200.

16. Lindberg, D., 1980. Science in the Middle Ages. University of Chicago Press, pp. 97-106.

17. Locke, J., Laslett, P., 1988. Locke: Two Treatises of Government. Student Cambridge Texts in the History of Political Thought. Cambridge University Press.

18. Wraight, C., 2008. Rousseau's 'The Social Contract'. A Reader's Guide A\&C Black.

19. United States Constitution. Date Views 12.09.2017. http://www. archives. gov/exhibits/charters/constitution.html

20. Horwitz, M., 1986. Book review (of E.P. Thompson. Whigs and Hunters). Yale Law Journal (1976-77): 561-66.

21. Universal Declaration of Human Rights. Date Views 15.08.2017. http://www.refworld.org.ru/docid/47a080da2.html (accessed 27 March 2018).
22. International Covenant on Economic, Social and Cultural Rights, adopted and opened for signature, ratification and accession by General Assembly resolution 2200A (XXI) of 16 December 1966, entry into force 3 January 1976, in accordance with article 27. Date Views 15.08.2017. http://www.ohchr.org/EN/ProfessionalInterest/Pages/ CESCR.aspx (accessed 27 March 2018).

23. Habermas, J., 1996. Between Facts and Norms. Contributions to a Discourse Theory of Law and Democracy. Cambridge. 